\title{
KAJIAN WAKTU CURING ASAM ASETAT DAN RASIO KOMBINASI KLOROFORM-ETANOL UNTUK EKSTRAKSI PROTEIN KULIT CEKER
}

\author{
MIWADA, I N.S., ${ }^{1)}$ DAN SIMPEN') \\ 1) FAKULTAS PETERNAKAN, UNIVERSITAS UDAYANA, DENPASAR \\ 2) JURUSAN KIMIA, FMIPA, UNIVERSITAS UDAYANA, DENPASAR \\ Email: nymsumerta@yahoo.co.id
}

\begin{abstract}
ABSTRAK
Telah dilakukan penelitian untuk menentukan waktu curing asam asetat dan rasio kloroform-etanol dalam upaya memisahkan komponen lemak dalam gelatin. Penelitian menggunakan rancangan acak kelompok (RAK), yaitu, sebagai kelompok yakni waktu curing (sebelum ektraksi pelarut dan setelah ektraksi pelarut) dan sebagai perlakuan yakni 3 jenis rasio ekstraksi pelarut jenis kloroform dan etanol yakni (1:1), (1:3), dan (3:1). Setiap unit perlakuan diulang 3 kali.Variabel penelitian yang diamati meliputi penentuan kadar air, protein, dan lemak gelatin. Hasil penelitian menunjukkan bahwa perbedaan waktu curing asam asetat dan perlakuan rasio ektraksi tidak memberikan pengaruh yang berbeda nyata terhadap kadar air dan protein gelatin. Sementara kadar lemak gelatin dipengaruhi secara nyata $(\mathrm{P}<0,05)$. Curing kulit ceker dengan asam asetat sebelum diekstraksi kloroform-etanol menghasilkan kadar lemak yang jauh lebih tinggi $(3,42 \%)$ dibandingkan dengan proses curing asam asetat dilakukan setelah ekstraksi klorofom-etanol (2,75\%) dan secara statistik berbeda nyata $(\mathrm{P}<0,05)$. Sementara, Kloroformetanol pada rasio (3:1) menghasilkan kemampuan mereduksi kandungan lemak gelatin lebih tinggi dibandingkan dengan kedua perlakuan lainnya. Kesimpulan penelitian bahwa curing asam asetat pada kulit ceker (konsentrasi 1,5\%) lebih baik dilakukan setelah diekstraksi kloroform- etanol dan rasio kloroform : etanol yang ideal yakni 3:1.
\end{abstract}

Kata kunci: waktu kuring, ekstraksi, gelatin

\section{THE ANALYSIS OF ACETIC ACID CURING TIME AND RATIO COMBINATION OF CHLOROFORM-ETHANOL FOR SKIN CLAWS PROTEIN EXTRACTION}

\begin{abstract}
The research was conducted to determine curing time of acetic acid and chloroform-ethanol ratio by separating fat component in the gelatin. Hence, the study was using a Randomized Block Design (RBD), grouped into curing times (pre-solvent extraction and post extraction solvent). There were three solvent extraction ratios (chloroform and ethanol) used as treatments with (1:1), (1:3), and (3:1) combinations. Each treatment was repeated for 3 (three) times. The variables observed were: moisture content, protein, and gelatin fat. The study showed that curing time differences of acetic acid and extraction ratio treatments did not significantly affected water content and protein of gelatin. Meanwhile, fat content of gelatin affected significantly $(\mathrm{P}<0.05)$. Curing skin claws with acetic acid in pre chloroform-ethanol extraction produced higher fat content (3.42\%) compared to curing acetic acid in post extraction chloroform-ethanol (2.75\%) and significantly different in statistic $(\mathrm{P}<0.05)$. The chloroform-ethanol in $(3: 1)$ ratio produced higher fat content reduction than the two other treatments. It can be concluded that acetic acid curing of skin claws (1.5\% concentration) performed better after extracted chloroform-ethanol with an ideal ratio (3:1).
\end{abstract}

Key words: curing-time, extraction and gelatin.

\section{PENDAHULUAN}

Kendala utama dalam hidrolisis protein kolagen dalam kulit adalah waktu pemisahan komponen lemak yang diduga ikut selama proses ekstraksi tersebut. Kandungan lemak yang masih tinggi akan menurunkan kualitas gelatin akibat produk mudah tengik selama pe- nyimpanan. Salah satu metode ekstraksi protein kolagen kulit dilakukan dengan curing asam. Sarkar (1995) menyebutkan bahwa kolagen bersifat tidak larut dalam larutan netral atau air tetapi larut dalam asam kuat. Prinsip penggunaan asam tersebut merupakan metode untuk membengkakan (swelling) kulit ternak sehingga pada saat ekstraksi selanjutnya bisa lebih cepat. Namun, 
metode curing ini belum efektif untuk mengurangi keberadaan lemak pada gelatin.

Ekstraksi dengan pelarut (ekstraksi padat-cair) adalah metode pemisahan (isolasi) suatu komponen dari campurannya dengan menggunakan pelarut yang sesuai, dimana zat yang diekstraksi terdapat di dalam campuran yang berbentuk padatan (Yazid, 2005). Ekstraksi minyak atau lemak adalah suatu cara untuk mendapatkan minyak atau lemak dari bahan yang diduga mengandung minyak atau lemak. Ekstraksi tersebut meliputi distribusi minyak atau lemak di dalam pelarut organik seperti kloroform, eter, atau heksana. Cara ekstraksi ada bermacam-macam, yaitu rendering, pengepresan, dan ekstraksi pelarut (Ketaren, 1986). Rendering merupakan suatu cara ekstraksi minyak atau lemak dari bahan yang diduga mengandung minyak atau lemak dengan kandungan air masih tinggi. Pengepresan merupakan suatu cara untuk mengekstraksi minyak atau lemak, terutama dari biji-bijian. Cara ini dilakukan untuk memisahkan minyak dari bahan yang berkadar minyak atau lemak tinggi (lebih dari 50\%). Umumnya, minyak atau lemak yang didapat juga masih banyak mengandung air. Sedangkan, ekstraksi dengan pelarut secara prinsip adalah ekstraksi dengan melarutkan minyak atau lemak dalam pelarut minyak atau lemak seperti kloroform, eter, atau heksana. Pada cara ini, kadar minyak atau lemak yang dapat ditarik (diambil) dari komponen yang ingin dihilangkan minyak atau lemaknya bisa mencapai di atas 99\%. Penelitian model ini pernah dilakukan oleh Sutini (1994), yaitu mengisolasi minyak pada daging buah adpokat melalui metode ekstraksi menggunakan pelarut petroleum eter. Ternyata, metode ekstraksi menggunakan pelarut kimia cukup efektif dalam mendapatkan minyak, dengan rendemen di atas 60\%. Namun demikian, dari hasil penelitian sebelumnya bahwa ekstraksi pelarut jenis kloroformmetanol ternyata malah menghambat proses hidrolisis protein kulit ceker (Miwada dan Simpen, 2007). Hal ini disebabkan karena kulit ceker menjadi kering dan sulit diekstraksi. Untuk itu perlu dilakukan penelitian dengan mengkombinasikan waktu curing dan kombinasi ekstraksi pelarut (kloroform - etanol) yang tepat sehingga komponen lemak pada gelatin bisa diminimalisir. Tujuan Penelitian ini adalah untuk menentukan waktu curing asam asetat dan rasio kloroform-etanol yang efektif dalam memisahkan komponen lemak pada gelatin.

\section{MATERI DAN METODE}

\section{Materi}

Bahan dasar penelitian ini adalah kaki broiler hasil limbah RPA di sekitar Kodya Denpasar. Bahan-bahan pendukung lainya adalah kloroform, etanol, asam asetat,
$\mathrm{HCl}$, buffer $\mathrm{pH}$ 4,o0, buffer $\mathrm{pH}$ 7,00, buffer $\mathrm{pH}$ 9,00, phenolphtalein (pp), aquades, kertas saring biasa, dan kertas saring Whatman 42. Alat-alat yang digunakan antara lain: peralatan gelas, piknometer, viskometer Oswald, thermometer, desikator, oven, water bath, timbangan analitik, panci aluminium, ember plastik, blender, kompor, dan loyang serta alat $\mathrm{pH}$ meter.

\section{Metode}

Preparasi: $10 \mathrm{~kg}$ ceker ayam broiler segar dikuliti dengan teknik pengulitan yang benar (Purnomo, 1992). Kulit yang diperoleh terlebih dahulu dipotong hingga berukuran kecil-kecil, dicuci dengan aquades, ditiriskan dan diangin-anginkan hingga kering lalu ditimbang beratnya untuk mengetahui persentase rendemen.

Kelompok I: 1000 gram kulit kaki ayam segar hasil preparasi di-curing menggunakan larutan asam asetat konsentrasi 1,5\%. Proses curing dilakukan selama 3 hari, lalu dicuci sampai benar-benar bersih (sampai menunjukkan $\mathrm{pH}$ netral atau tes negatif terhadap indikator pp). Secara terpisah, 250 gram kulit kaki ayam broiler yang telah dicuring asam tersebut lalu diekstraksi di dalam corong pisah dengan $250 \mathrm{~mL}$ campuran pelarut kloroform-etanol perbandingan (1:1), (1:3), dan (3:1) selama 1 jam (dikocok tiap 10 menit). Setelah ekstraksi dilakukan selama 1 jam, bagian (lapisan) air dipisahkan lalu dilanjutkan dengan penyaringan, penguapan larutan pengekstrak (pada suhu $70^{\circ} \mathrm{C}$ ), dan pengentalan produk gelatin yang diperoleh.

Kelompok II: dalam tempat terpisah, masing-masing 250 gram kulit kaki ayam segar hasil preparasi diekstraksi dengan $250 \mathrm{~mL}$ campuran pelarut kloroform-etanol perbandingan 1:1, 1:3, dan 3:1 selama 1 jam (dikocok tiap 10 menit). Setelah ekstraksi dilakukan selama 1 jam, dilanjutkan dengan pencucian, penyaringan, penguapan larutan pengekstrak. Selanjutnya, kulit kaki ayam yang telah terekstrak tersebut dilakukan curing menggunakan larutan asam asetat konsentrasi 1,5\%. Proses curing dilakukan selama 3 hari, lalu dicuci sampai benar-benar bersih (sampai menunjukkan $\mathrm{pH}$ netral atau tes negatif terhadap indikator pp), selanjutnya produk gelatin yang diperoleh dikentalkan.

Penelitian menggunakan rancangan acak kelompok (RAK) yakni 2 jenis kelompok (I dan II) dan 3 jenis perbandingan kombinasi ekstraksi (1:1), (1:3), dan (3:1). Masing-masing unit perlakuan diulang sebanyak 3 kali.

Variabel yang diamati meliputi uji kadar air, lemak dan protein dengan metode AOAC (1985). Penelitian dilaksanakan di Laboratorium Teknologi Hasil Ternak, Fakultas Peternakan dan Lab. Kimia Fisik, Jurusan Kimia FMIPA, Universitas Udayana. Data dianalisis dengan sidik ragam dan bila terdapat perbedaan yang nyata dilanjutkan dengan uji Duncan (Steel dan Torrie, 1980). 


\section{HASIL DAN PEMBAHASAN}

Gelatin yang dihasilkan pada penelitian (Tabel 1) ini adalah gelatin segar/basah. Secara keseluruhan kualitas gelatin yang dihasilkan pada penelitian ini, khususnya untuk indikator kadar air berkisar antara 89,23\%90,26\%. Pearson dan Dutson (1992) menyebutkan bahwa kadar air gelatin pada kondisi asam berkisar antara 1-4\% dalam satuan berat kering. Tidak ditemukan bukti bahwa perbedaan waktu curing asam asetat (konsentrasi 1,5\%) maupun perbedaan rasio ekstraksi pelarut (kloroform-etanol) nyata mempengaruhi kadar air gelatin yang dihasilkan.

Tabel 1. Kadar Air Gelatin Hasil Ekstraksi Protein Ceker dengan Kloroform-Etanol pada Waktu Curing Berbeda

\begin{tabular}{cccc}
\hline \multirow{2}{*}{$\begin{array}{c}\text { Rasio Kloroform- } \\
\text { Etanol }\end{array}$} & \multicolumn{2}{c}{ Waktu Curing Asam Asetat } & \multirow{2}{*}{ Rerata } \\
\cline { 2 - 3 } $1: 1$ & Awal & akhir & \\
\hline $1: 3$ & 89,48 & 89,99 & $89,73^{\mathrm{a}}$ \\
$3: 1$ & 89,89 & 88,85 & $89,37^{\mathrm{a}}$ \\
Rerata & 90,26 & 89,23 & $89,75^{\mathrm{a}}$ \\
\hline
\end{tabular}

Protein adalah salah satu komponen penting dalam suatu produk termasuk produk gelatin dari ekstraksi kulit ceker. Hasil penelitian (Tabel 2) menunjukkan bahwa waktu curing dengan asam asetat pasca ekstraksi kloroform-etanol menghasilkan kadar protein gelatin yang cenderung lebih tinggi dibandingkan dengan dilakukan diawal ekstrasi. Hal ini kemungkinan disebabkan karena curing diawal lebih berpeluang merusak protein lebih besar. Terbukti kulit ceker menjadi bengkak (swelling) yang merupakan pertanda telah terjadi denaturasi dan kondisi ini tidak mampu mempertahankan ikatan protein yang ada dan ikatannya cenderung lemah (Sharpouse, 1989). Kemampuan kloroform-etanol (rasio 1:1) sebagai ekstraksi pelarut protein kolagen ceker cenderung menghasilkan kadar protein gelatin yang lebih besar dibandingkan dengan kombinasi rasio lainnya.

Tabel 2. Kadar Protein Gelatin Hasil Ekstraksi Protein Ceker dengan Kloroform-Etanol pada Waktu Curing Berbeda

\begin{tabular}{cccc}
\hline $\begin{array}{c}\text { Rasio Kloroform - } \\
\text { Etanol }\end{array}$ & \multicolumn{2}{c}{ Waktu Curing Asam Asetat } & \multirow{2}{*}{ Rerata } \\
\cline { 2 - 3 } $1: 1$ & 7,48 & akhir & \\
$1: 3$ & 6,66 & 7,92 & $7,70^{\text {a }}$ \\
$3: 1$ & 7,81 & 8,26 & $7,46^{\text {a }}$ \\
Rerata & $7,32^{\mathrm{A}}$ & 6,84 & $7,32^{\mathrm{a}}$ \\
\hline
\end{tabular}

Penggunaan pelarut jenis kloroform yang dikombinasikan dengan etanol pada proses ekstraksi protein kolagen kulit ceker bertujuan untuk mengikat komponen lemak yang masih terdapat pada gelatin. Hasil penelitian (Tabel 3) menunjukkan bahwa terdapat perbedaan $(\mathrm{P}<0,05)$ yang nyata bila curing asam asetat di- lakukan diawal dengan diakhir ekstraksi Curing asam diakhir/pasca ekstraksi kulit ceker dengan kloroformetanol mampu menurunkan kadar lemak yang terkandung pada produk gelatin.

\begin{tabular}{|c|c|c|c|}
\hline \multirow{2}{*}{$\begin{array}{c}\text { Rasio Kloroform - } \\
\text { Etanol }\end{array}$} & \multicolumn{2}{|c|}{ Waktu Curing Asam Asetat } & \multirow[t]{2}{*}{ Rerata } \\
\hline & Awal & akhir & \\
\hline $1: 1$ & 3,63 & 2,81 & $3,22^{a}$ \\
\hline $1: 3$ & 3,67 & 2,81 & $3,24^{a}$ \\
\hline $3: 1$ & 2,97 & 2,62 & $2,80^{b}$ \\
\hline Rerata & $3,42^{A}$ & $2,75^{\mathrm{B}}$ & \\
\hline
\end{tabular}

Pembengkakan protein kulit akan menyebabkan sulitnya untuk memisahkan antara protein dengan lemak dibandingkan bila curing dilakukan diakhir ekstraksi. Curing yang dilakukan setelah ekstraksi dengan kloroform-etanol menghasilkan kulit yang masih utuh dan cenderung kering sehingga diduga proses pemisahan protein dan lemak menjadi lebih mudah. Proporsi kloroform-etanol pada tingkat rasio 3:1 mampu efektif memisahkan kadar lemak yang ditemukan pada gelatin dengan kadar lemak gelatin yang dihasilkan lebih rendah $(\mathrm{P}<0,05)$ dibanding kedua perlakuan lainnya. Degresing lemak (penghilangan lemak) pada proses produksi gelatin menjadi penting, mengingat didalam standar yang dibuat oleh Pearson dan Dutson (1992) maupun dalam Standar Industri Indonesia (1985) tidak ada tercantum kadar lemak pada produk gelatin. Disamping itu, tingginya kadar lemak pada produk gelatin akan berdampak pada kerusakan gelatin selama penyimpanan akibat terjadinya ransiditas.

Kesimpulan yang didapat dari hasil kajian penelitian ini bahwa pemisahan lemak dengan ekstraksi pelarut (kloroform-etanol) cukup efektif pada ratio (3:1) dengan syarat curing asam asetat (konsentrasi 1,5\%) dilakukan setelah tahap ekstraksi pelarut selesai dikerjakan. $\mathrm{Cu}-$ ring asam asetat yang dilakukan sebelum tahap ekstraksi dengan pelarut kloroform-etanol tidak efektif untuk memisahkan lemak yang terkandung didalam gelatin. Penelitian ini telah mampu menurunkan kandungan lemak gelatin namun belum total seperti yang direkomendasikan dalam SNI

\section{DAFTAR PUSTAKA}

Anonim. 1985, "Standard Industri Indonesia", Departemen Kesehatan RI, Jakarta.

AOAC (Asssociation of Official Analytical Chemists). 1985. Official Methode of Analysis. $12^{\text {th }}$ Ed. PO Box 540. Benyamin Franklin Station, Washington

Ketaren, S. 1986. Pengantar Teknologi Minyak dan Lemak Pangan. Penerbit UI Press. Jakarta.

Miwada, INS. dan Simpen, IN. 2007. Optimalisasi Potensi Ceker Ayam (Shank) Hasil Limbah RPA Melalui Metode 
Ekstraksi Termodifikasi. Majalah Ilmiah Peternakan, vol 10 (1): 5-8.

Pearson, A.M., and Dutson T.R. 1992, "Inedible Meat by Product Advances in Meat", Research, Vol. 8, London dan New York.

Sarkar, K.T. 1995. "Theory and Practice of Leather Manufacture", Publ. The Author 4. Second Avenue Mahatma Gandhi Road, Madras.

Sharphouse, J.H. 1989. Leather Technician's Handbook. Leather Producers Association, London

Steel, R.G. dan Torrie, J.H. 1980. Principle and Procedure of Statistic. McGraw Hill Book Company, Inc., New York.

Sutini, NW. 1994. Isolasi dan Analisis Minyak Pada Daging Buah Adpokat (Persea americana Mill). Skripsi. Program Studi Kimia, Universitas Udayana, Denpasar.

Yazid, E. 2005. Kimia Fisika untuk Paramedis. Penerbit Andi, Yogyakarta. 